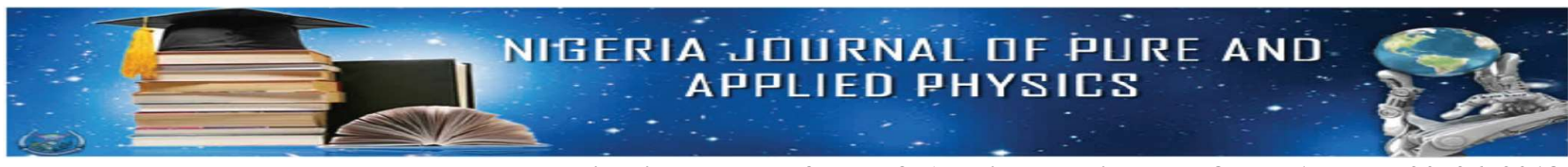

Nigeria Journal of Pure \& Applied Physics, Vol. 8, No. 1, pages 20-26, 2018

\title{
Natural Radioactivity Measurement of Water and Sediment from the Historic Ikogosi Warm and Cold Spring, Nigeria.
}

\author{
Ibikunle S. B., Arogunjo A. M., Ajayi O. S., Oluyide S. S. \\ Department of Physics, Federal University of Technology, \\ P. M. B. 704, Akure, Ondo State. Nigeria. \\ Mobile: $+2348037218023,+918197130964$ \\ †Corresponding Author’s Email: tuncom7084@,yahoo.co.uk
}

\begin{abstract}
Natural radioactivity measurement and the resultant risk assessment in the water and sediments from the historic Ikogosi warm and cold spring were carried out. A total of 8 samples (4 water and 4 sediment samples) were collected from the Ikogosi spring resort. A sample each was collected from the warm spring, cold spring, meeting point and a sample outside the resort. The samples were thoroughly prepared following the IAEA recommended procedures and analyzed for ${ }^{40} \mathrm{~K},{ }^{238} \mathrm{U}$, and ${ }^{232} \mathrm{Th}$ using $\mathrm{NaI}(\mathrm{Tl})$ detector. The activity concentrations of ${ }^{40} \mathrm{~K},{ }^{238} \mathrm{U}$ and ${ }^{232} \mathrm{Th}$ in water samples range from $40.14 \pm 17.83$ to $67.59 \pm 19.87 \mathrm{~Bq} \mathrm{~L}^{-1}, 8.15 \pm 2.84$ to $11.14 \pm 3.78 \mathrm{~Bq} \mathrm{~L}$ and $5.71 \pm 1.32$ to $8.24 \pm 2.61 \mathrm{~Bq} \mathrm{~L}^{-1}$ respectively. The activity concentration of sediment samples range from $136.31 \pm 17.01$ to $246.21 \pm$ $34.93 \mathrm{~Bq} \mathrm{~kg}^{-1}, 17.98 \pm 7.64$ to $28.32 \pm 5.98 \mathrm{~Bq} \mathrm{~kg}^{-1}$ and $9.57 \pm 3.15$ to $16.12 \pm 3.41 \mathrm{~Bq} \mathrm{~kg}^{-1}$ respectively. These values compared reasonably well with the worldwide average concentrations of $400 \mathrm{~Bq} \mathrm{~kg}^{-1}, 40 \mathrm{~Bq} \mathrm{~kg}^{-1}, 40 \mathrm{~Bq} \mathrm{~kg}^{-1}$ for ${ }^{40} \mathrm{~K},{ }^{238} \mathrm{U}$, and ${ }^{232} \mathrm{Th}$ respectively. The mean absorbed dose rate in air obtained for sediment was $40.33 \mathrm{nGy} \mathrm{h}^{-1}$, while the annual outdoor effective dose equivalent was $49.46 \mu \mathrm{Sv} \mathrm{y}^{-1}$, which is lower than the world average of $70 \mu \mathrm{Sv} \mathrm{y}^{-1}$ specified by UNSCEAR for an outdoor effective dose. The total annual effective dose due to ingestion of radionuclides in the water for 3 age groups range from 13.414.87 to $18.856 .43 \mathrm{mSv} \mathrm{y}^{-1}, 2.751 .03$ to $5.722 .13 \mathrm{mSv} \mathrm{y}^{-1}$ and 2.621.01 to $4.951 .43 \mathrm{mSv} \mathrm{y}^{-1}$ for infants $(0-1 \mathrm{y})$, children $(7-12 \mathrm{y})$ and adult $(>17 \mathrm{y})$ respectively. These values were higher than $1 \mathrm{mSv} \mathrm{y}^{-}$ ${ }^{1}$ recommended by ICRP.
\end{abstract}

Key Words: Natural Radioactivity, Activity concentrations, Cold spring, Ikogosi, Nigeria

\section{INTRODUCTION}

Water and soil are two important and indispensable needs for human existence. It has been reported that in infants, 75\% of body weight contributes to water and $55 \%$ of body weight in the elderly (Nicolaidis 1998), which is responsible for most of its metabolic activities. Human dietary intakes (either liquid or solid) has a direct link with either water or soil (Science Communication Unit, 2013). This makes it necessary to study the activity levels of the radionuclides inherent in water and /or soil. The major sources of water available for man derived their origin from the soil. The radionuclide content in water supply has a direct relationship with the source. It has been reported that primordial radionuclide like ${ }^{40} \mathrm{~K},{ }^{238} \mathrm{U}$, and ${ }^{232} \mathrm{Th}$ are common in earth crust, while the daughters radionuclide of ${ }^{226} \mathrm{Ra},{ }^{228} \mathrm{Ra}$ series and non series ${ }^{40} \mathrm{~K}$ are common in water (Ajayi and Owolabi 2007; Akinloye, 2008). Natural radionuclides in soil and water of a particular environment are distributed by natural geological and geochemical setting of an area (Trimble 1968). Natural radionuclides and other progenies could be radiotoxic and carcinogenic when present at enhanced levels in water, food and the environment. The ingestion or inhalation of these radionuclides poses serious risks to the body organs depending on the metabolism of the element involved and the radiosensitivity of the target organ (Wall et al, 2011).

${ }^{226} \mathrm{Ra}$ posed high radiological risk especially in water. Their presence in drinking water and associated biological effect can lead to serious health detriment. When the populace is exposed to high level of radium-226 over a period of time, cancer of bone and nasal cavity could result (Nour 2004, Rowland 1993). Radioactivity level in water samples from Nigeria have been studied as reported by other researchers (Olomo et al., 1994; Avwiri 2005, Ajayi and Adesida, 2009). In this study, samples of Ikogosi warm and cold spring with their respective sediment samples within the same location were collected for analysis to determine the activity concentration of natural radionuclide in the sediments and water from Ikogosi springs. Ikogosi warm and cold spring is an historic site that has been attracting many tourists all over the world. The water from the spring is being used for production of sachet and bottled water being consumed by many Nigerians, most especially in the south-western part of the country. Assessment of radiological parameters and the 
associated risk is therefore necessary for environmental radiological protection. The aim of this work is to measure the activity concentrations of natural Radionuclides in water and sediment from Ikogosi warm and cold spring resort and use the data obtained to estimate its radiological impact.

\section{MATERIALS AND METHOD}

From the study area of Ikogosi spring resort, eight (8) samples (4 water samples and 4 sediments samples) were collected from the warm spring, cold spring, meeting point within the resort and a sample outside the resort. Each water sample was collected in a clean $75 \mathrm{cl}$ plastic container. Before the collection of each sample from the spring, some of the water from the spring was used to rinse the plastic containers and after collection, each one of them was acidified with $11 \mathrm{M}$ HCL solution at the rate of $10 \mathrm{ml}$ per litre of sample. This was done to avoid absorption of radionuclide into the walls of the plastic container and also prevents the release of any radionuclide already absorbed back into the samples. In the laboratory, water samples were poured into marinelli beakers. Each beaker of volume of 1 litre was first rinsed with dilute Sulphuric Acid $\left(\mathrm{H}_{2} \mathrm{SO}_{4}\right)$, then the water sample was poured into the beaker, labelled, sealed and left for about 30 days to attain a state of secular equilibrium between the parent and daughter radionuclides in the water sample. After the time for secular equilibrium,, the samples were inserted one after the other into the $\mathrm{NaI}(\mathrm{Tl})$ detector and the activity concentration of the radionuclide were measured.

Sampling of the sediment was carried out at the same point where the water samples were collected, packed into cellophane bags and taken into laboratory for gamma spectrometric analysis. The sediment samples were processed according to the recommended procedure by the IAEA (1989). The collected soil sediment sample was sundried and oven dried at a temperature of about $110^{\circ} \mathrm{C}$ to remove its moisture content and reduce the samples to a constant mass. The resulting dried samples were then pulverized by grinding it into a powdery form. The powdered samples were then sieved with a $2 \mathrm{~mm}$ mesh to obtain a fine texture of sediment samples. $200 \mathrm{~g}$ of each sample was then measured into each plastic geometry bottle and sealed for a period of 30 days to also achieve a state of secular equilibrium between the parent and daughter radionuclides present in the sample. The sediment samples were subjected to gamma spectroscopy to determine the activity.

\section{Measurement Techniques}

The gamma analysis was performed on a Sodium Iodide (Thallium doped) $\mathrm{NaI}(\mathrm{Tl})$ scintillation detector. The output of the detector was connected to a Canberra Series 10 plus Portable Multichannel Analyzer (MCA) which recorded the gamma spectra of the soil sediment samples as well as background radiation. $200 \mathrm{~g}$ of the soil sample was weighed out and transferred to a 0.573 litre capacity container for gamma analysis. The counting time for background radiation in the soil sediment sample was 2 hours $(7,200$ s).

For calibration, a sand standard radionuclide source was prepared using $0.07721 \mathrm{~g}$ measured gravimetrically from a master radionuclide solution source which was calibrated using the $\mathrm{NaI}(\mathrm{Tl})$ gamma spectrometer system. The gamma spectroscopy analysis was based on a computer program which matched gamma energy at various energy levels to a library of possible isotopes. For the purpose of this study, three regions of interest were defined for ${ }^{40} \mathrm{~K},{ }^{238} \mathrm{U}$ and ${ }^{232} \mathrm{Th}$. ${ }^{232} \mathrm{Th}$ concentration in soil was determined by the $911 \mathrm{keV}$ gamma lines of ${ }^{228} \mathrm{Ac}$ while the ${ }^{238} \mathrm{U}$ concentrations were determined by the $609 \mathrm{keV}$ gamma lines of ${ }^{214} \mathrm{Bi}$. The activity concentration of ${ }^{40} \mathrm{~K}$ was determined from the peak areas at $1460 \mathrm{keV}$.

\section{The Study Area}

The Ikogosi Spring resort is tourist centre located at Ikogosi, a town in Ekiti State, Southwestern Nigeria. Flowing abreast the warm spring is another cold spring that meets the warm spring at a confluence but each maintaining its thermal properties. This makes the springs a tourist attraction in Nigeria.

Ikogosi is an ancient town in the western part of Ekiti State in the South-Western Nigeria. It is situated between lofty, steep-sided and heavily wooded, north-south trending hills about $27.4 \mathrm{~km}$ east of Ilesha (Osun State), and about $10.5 \mathrm{~km}$ southeast of Effon Alaye (Ekiti State). It is located just at the north of the $7^{\circ} 35^{\prime} \mathrm{N}$ latitude and slightly west of the $5^{\circ} 00^{\prime} \mathrm{E}$ longitude. The general elevation of the area is between 457.0 and $487.5 \mathrm{~m}$. Ikogosi warm and cold spring is an historic feature. The unique natural occurrence that causes two different springs of different temperatures (warm and cold) from close collection of rocks, flow at different directions, meet again at a point and flow in the same direction, makes the place an attraction for tourism and recreation

\section{Radiological Assessment}

Estimation of annual effective dose $E_{d}\left(S v y^{-1}\right)$ to an individual due to the ingestion of the natural radionuclides present in the spring water was determined using the following relation by Alam et al. (1999) 


$$
E_{d}=A_{c} A_{i} C_{f}
$$

Where $A_{c}$ is the activity concentration of the radionuclide in the well or borehole Water $\left(\mathrm{Bq} \mathrm{L}^{-1}\right), \mathrm{A}_{\mathrm{i}}$ is the consumption per annum or annual intake of drinking water and $\mathrm{C}_{\mathrm{f}}$ is the ingested dose conversion factor for radionuclides $\left(\mathrm{Sv} \mathrm{Bq}^{-1}\right)$, which varies for different radionuclides and the age of individual.

The total effective dose $\mathrm{D}\left(\mathrm{Sv} \mathrm{y}^{-1}\right)$ to an individual was established by summing contributions from all radionuclides present in the water samples, i.e ${ }^{40} \mathrm{~K},{ }^{238} \mathrm{U}$ and ${ }^{232} \mathrm{Th}$.

$$
D=\sum A_{c} A_{i} C_{f}
$$

The conversion factors used in this work were taken from EC Directive 96/29 (European Commission Directive, 1996). The annual effective dose values were calculated for three different age groups (0-1yr, 7-12yr, >17yr) i .e babies, Children and Adult.

The annual intake of water for the three different age groups was extracted from the publication of World Health Organization (WHO, 2003). The committed effective dose $\mathrm{C}_{\mathrm{d}}$ which is a measure of the total effective dose received over an average life time of 50 years was calculated for the age $>17$ years due to the ingestion of radionuclides using the relation

$$
C_{d}=50 \times D
$$

Where $\mathrm{D}$ is the total effective dose to an individual The annual Effective Dose due to exposure of these radionuclides from the soil was estimated taking into consideration the conversion coefficient from absorbed dose in air to effective dose and the outdoor occupancy factor. The former gives the equivalent human dose in $\mathrm{Sv} \mathrm{y}^{-1}$ from the absorbed dose rate in air $\left(\mathrm{nGy} \mathrm{h}^{-1}\right)$, while the latter gives the fraction of the time an individual is exposed. In this work, an occupancy factor of 0.3 was used (i.e. an individual is assumed to spend an average of 8 hours outdoor) and $0.7 \mathrm{~Sv}$ $\mathrm{y}^{-1}$ was used for the conversion co efficient according to UNSCEAR report of 1988, 1993 and 2000. Hence the annual effective dose rate, $\mathrm{H}_{\mathrm{E}}$, in units of $\mu \mathrm{Sv}^{-1}$, is calculated using the following relation:

$$
H_{E}=D(\gamma) \times N(h) \times O_{f} \times C_{f}
$$

Where $\mathrm{D}(\gamma)$ is the calculated absorbed dose $\left(\mathrm{nGy} \mathrm{h}^{-1}\right), \mathrm{N}(\mathrm{h})$ is the number of hours in a year () $\mathrm{O}_{\mathrm{f}}$ is the occupancy factor (i.e. 0.3$)$ and $\mathrm{C}_{\mathrm{f}}$ is the conversion co efficient or factor $(0.7$ $\left.\mathrm{Sv} \mathrm{Gy}^{-1}\right)$.

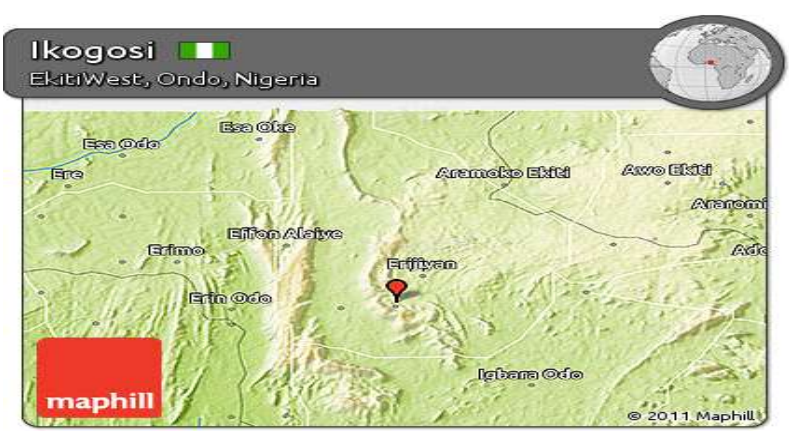

FIGURE 1: THE MAP OF IKOGOSI ((Source: http://www.maphill.com/nigeria/ekitiwest/ikogosi)

\section{RESULTS AND DISCUSSION}

The activity concentrations of the naturally occurring radionuclides in the water samples and sediment samples are

\begin{tabular}{|c|c|c|c|}
\hline \multirow{3}{*}{$\begin{array}{l}\text { Sample } \\
\mathrm{S} / \mathrm{N}\end{array}$} & \multicolumn{3}{|c|}{ Activity Concentrations } \\
\hline & $\mathrm{K}-40$ & U-238 & Th-232 \\
\hline & & (Ra-226) & (Ra-228) \\
\hline \multicolumn{4}{|c|}{ Water $\left(\mathrm{Bq} \mathrm{L} \mathrm{L}^{-1}\right)$} \\
\hline 1 warm spring water & $57.24 \pm 14.36$ & $8.24 \pm 3.68$ & $6.40 \pm 2.43$ \\
\hline 2 cold spring water & $62.53 \pm 21.08$ & $9.87 \pm 4.56$ & $7.29 \pm 3.01$ \\
\hline 3 meeting point(warm/cold) & $67.59 \pm 19.87$ & $11.14 \pm 3.78$ & $8.24 \pm 2.61$ \\
\hline 4 water outside the resort & $40.14 \pm 17.83$ & $8.15 \pm 2.84$ & $5.71 \pm 1.32$ \\
\hline Range & $40.14 \pm 67.59$ & $8.15 \pm 11.14$ & $5.17 \pm 8.24$ \\
\hline Mean & $56.88 \pm 18.29$ & $9.35 \pm 3.72$ & $6.91 \pm 2.34$ \\
\hline \multicolumn{4}{|c|}{ Sediment $\left(\mathrm{Bq} \mathrm{kg}^{-1}\right)$} \\
\hline 5 from warm spring & $230.22 \pm 36.58$ & $19.20 \pm 4.82$ & $16.12 \pm 3.41$ \\
\hline 6 from cold spring & $222.13 \pm 29.74$ & $21.03 \pm 6.55$ & $14.23 \pm 5.14$ \\
\hline 7 from meeting point & $246.21 \pm 34.93$ & $28.32 \pm 5.98$ & $11.97 \pm 4.12$ \\
\hline 8 from outside the resort & $136.31 \pm 17.01$ & $17.98 \pm 7.64$ & $9.57 \pm 3.15$ \\
\hline \multirow[t]{2}{*}{ Range } & $136.31-$ & $17.98-$ & $9.57-$ \\
\hline & 246.21 & 28.32 & 16.12 \\
\hline Mean & $208.72 \pm 29.57$ & $21.63 \pm 6.25$ & $12.97 \pm .96$ \\
\hline
\end{tabular}
shown in Table 1 below.

Table 1: Activity Concentrations of Radionuclides in Both Water and Sediment Samples.

\section{Activity Concentrations in Water Samples}

The activity concentration of natural radionuclides which includes ${ }^{40} \mathrm{~K},{ }^{238} \mathrm{U}$, and ${ }^{232} \mathrm{Th}$ had been detected in the water samples collected in the study area. ${ }^{40} \mathrm{~K}$ was found to record 
the highest activity concentration in every sample analyzed. The concentrations obtained for K-40 ranged from $40.14 \pm$ 17.83 to $67.59 \pm 19.87 \mathrm{~Bq} \mathrm{~L}^{-1}$ with a mean of $56.88 \pm 18.29$ $\mathrm{Bq} \mathrm{L}^{-1}$, for $\mathrm{U}-238$ ranged from $8.15 \pm 2.84$ to $11.14 \pm 3.78$ $\mathrm{Bq} \mathrm{L}^{-1}$ with a mean of $9.35 \pm 3.72 \mathrm{~Bq} \mathrm{~L}^{-1}$, for Th-232 ranged from $5.71 \pm 1.32$ to $8.24 \pm 2.61 \mathrm{~Bq} \mathrm{~L}^{-1}$ with an average of $6.91 \pm 2.34 \mathrm{~Bq} \mathrm{~L}^{-1} \cdot{ }^{40} \mathrm{~K}$ recording the highest activity concentration is not strange because it is a naturally occurring radionuclide which abounds in the earth crust. The specific activity due to ${ }^{232} \mathrm{Th}$ is relatively low in the water samples investigated compared to ${ }^{238} \mathrm{U}$ because ${ }^{238} \mathrm{U}$ is more mobile than ${ }^{232}$ Th NCRP (1987)

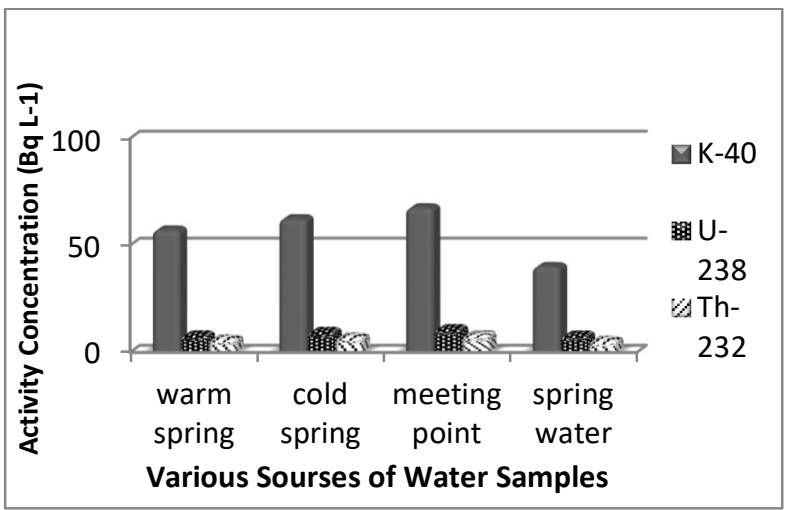

Figure 2 Activity Concentration of Primordial

Radionuclides in the Water Samples

Table 2: Annual Effective Dose for Three Different age Groups and Committed Effective Dose

\begin{tabular}{|c|c|c|c|c|c|c|c|}
\hline & $\begin{array}{r}\text { K-40. Activity } \\
\text { Conc Bq L L }\end{array}$ & $\begin{array}{c}\text { U-238 } \\
\text { Activity } \\
\text { Conc Bq } \\
\mathrm{L}^{-1}\end{array}$ & $\begin{array}{c}\text { Th-232 } \\
\text { Activity } \\
\text { Conc Bq } \\
\mathrm{L}^{-1}\end{array}$ & $\begin{array}{l}\text { Annual } \\
\text { Effectiv } \\
\text { e Dose, } \\
(0-1 \mathrm{y}) \\
\mathrm{mSv} \mathrm{y}^{-1}\end{array}$ & $\begin{array}{c}\text { Annual } \\
\text { Effecti } \\
\text { ve } \\
\text { Dose, } \\
(7-12 y) \\
\text { mSv y } \\
1\end{array}$ & $\begin{array}{c}\text { Annual } \\
\text { Effecti } \\
\text { ve } \\
\text { Dose }> \\
17 \mathrm{y}) \\
\mathrm{mSv} \mathrm{y}^{-1}\end{array}$ & $\begin{array}{l}\text { Committ } \\
\text { ed } \\
\text { Effectiv } \\
\mathrm{e} \\
\text { Dose }(>1 \\
7 \mathrm{y}) \\
\mathrm{mSv} \mathrm{y}^{-1}\end{array}$ \\
\hline $\begin{array}{l}\text { warm spring } \\
\text { water }\end{array}$ & $57.24 \pm_{14.36}$ & $8.24 \pm 3.68$ & $\begin{array}{c}6.40 \pm \\
2.43\end{array}$ & $\begin{array}{c}13.63 \pm \\
5.69\end{array}$ & $\begin{array}{r}3.67 \pm \\
1.55\end{array}$ & $\begin{array}{r}2.76 \pm \\
1.16\end{array}$ & $\begin{array}{c}138.00 \pm \\
58.00\end{array}$ \\
\hline $\begin{array}{l}\text { cold spring } \\
\text { water }\end{array}$ & $62.53 \pm_{21.08}$ & $9.87 \pm 4.56$ & $\begin{array}{c}7.29 \pm \\
3.01\end{array}$ & $\begin{array}{c}15.99 \pm \\
7.32\end{array}$ & $\begin{array}{r}4.34 \pm \\
2.45\end{array}$ & $\begin{array}{r}3.54 \pm \\
1.64\end{array}$ & $\begin{array}{c}177.00 \pm \\
82.00\end{array}$ \\
\hline $\begin{array}{l}\text { meeting point } \\
\text { (warm/cold) }\end{array}$ & $67.59 \pm 19.87$ & $11.14 \pm 3.78$ & $\begin{array}{c}8.24 \pm \\
2.61\end{array}$ & $\begin{array}{c}18.85 \pm \\
6.43\end{array}$ & $\begin{array}{r}5.72 \pm \\
2.13\end{array}$ & $\begin{array}{r}4.95 \pm \\
1.43\end{array}$ & $\begin{array}{c}247.50 \pm \\
71.50\end{array}$ \\
\hline $\begin{array}{l}\text { Water } \\
\text { outside the }\end{array}$ & $40.141 \pm 7.83$ & $8.15 \pm 2.84$ & $\begin{array}{c}5.71 \pm \\
1.32\end{array}$ & $\begin{array}{c}13.41 \pm \\
4.87\end{array}$ & $\begin{array}{r}2.75 \pm \\
1.03\end{array}$ & $\begin{array}{r}2.62 \pm \\
1.01\end{array}$ & $\begin{array}{c}131.00 \pm \\
50.50\end{array}$ \\
\hline
\end{tabular}

resort
Table 3: Radionuclides and their Ingested Dose Conversion Factor

\begin{tabular}{lllllll} 
Radionucli & \multicolumn{6}{c}{ Ingested Dose Conversion Factor Per Age Group } \\
de & $(0-$ & $(1-$ & $(2-$ & $(7-$ & $(12-$ & $>17 \mathrm{yrs}$ \\
& $1) \mathrm{yr}$ & $2) \mathrm{yrs}$ & $7) \mathrm{yrs}$ & $12) \mathrm{yrs}$ & $17) \mathrm{yrs}$ & $\mathrm{Sv} / \mathrm{Bq}$ \\
& $\mathrm{Sv} / \mathrm{B}$ & $\mathrm{Sv} / \mathrm{Bq}$ & $\mathrm{Sv} / \mathrm{Bq}$ & $\mathrm{Sv} / \mathrm{Bq}$ & $\mathrm{Sv} / \mathrm{Bq}$ & \\
& $\mathrm{q}$ & & & & & \\
& $6.2 \mathrm{E}-8$ & $4.2 \mathrm{E}-8$ & $2.1 \mathrm{E}-8$ & $1.3 \mathrm{E}-8$ & $7.6 \mathrm{E}-9$ & $6.2 \mathrm{E}-9$ \\
${ }^{40} \mathrm{~K}$ & $1.4 \mathrm{E}-9$ & $7.4 \mathrm{E}-10$ & $3.6 \mathrm{E}-10$ & $2.1 \mathrm{E}-10$ & $1.4 \mathrm{E}-10$ & $1.0 \mathrm{E}-10$ \\
${ }^{214} \mathrm{Bi}$ & $2.7 \mathrm{E}-9$ & $1.0 \mathrm{E}-9$ & $5.2 \mathrm{E}-10$ & $3.1 \mathrm{E}-10$ & $2.0 \mathrm{E}-10$ & $1.4 \mathrm{E}-10$ \\
${ }^{214} \mathrm{~Pb}$ & $2.7 \mathrm{E}-6$ & $6.6 \mathrm{E}-7$ & $3.5 \mathrm{E}-7$ & $2.6 \mathrm{E}-7$ & $2.0 \mathrm{E}-7$ & $6.5 \mathrm{E}-8$ \\
${ }^{224} \mathrm{Ra}$ & $4.7 \mathrm{E}-6$ & $9.6 \mathrm{E}-7$ & $6.2 \mathrm{E}-7$ & $8.0 \mathrm{E}-7$ & $1.5 \mathrm{E}-6$ & $2.8 \mathrm{E}-7$ \\
${ }^{226} \mathrm{Ra}$ & $7.4 \mathrm{E}-9$ & $2.8 \mathrm{E}-9$ & $1.4 \mathrm{E}-9$ & $8.7 \mathrm{E}-10$ & $5.3 \mathrm{E}-10$ & $4.3 \mathrm{E}-10$ \\
${ }^{228} \mathrm{Ac}$ & $4.6 \mathrm{E}-6$ & $4.5 \mathrm{E}-7$ & $3.5 \mathrm{E}-7$ & $2.9 \mathrm{E}-7$ & $2.5 \mathrm{E}-7$ & $2.3 \mathrm{E}-7$
\end{tabular}

Table 4: Annual Water Consumption for Different Age Groups

$\begin{array}{cc}\begin{array}{c}\text { AGE GROUP } \\ (\mathbf{y})\end{array} & \begin{array}{c}\text { ANNUAL WATER } \\ \text { CONSUMPTION }\left(\mathbf{l y}^{-1}\right)\end{array} \\ 0-1 & 2.0 \mathrm{E} 2 \\ 1-2 & 2.6 \mathrm{E} 2 \\ 2-7 & 3.0 \mathrm{E} 2 \\ 7-12 & 3.5 \mathrm{E} 2 \\ 12-17 & 6.0 \mathrm{E} 2 \\ >17 & 7.3 \mathrm{E} 2\end{array}$

Source: WHO, 2003

\section{Annual Effective Dose Equivalent $E_{d}(\mathrm{~Sv} / \mathrm{y})$}

In this study, only three age groups were considered for the different age groups infant (0-1 y), Children (7-12 y) and Adult (>17 y)

The variation for different age groups with ingested dose conversion factor was provided by IAEA (1996) and shown in Table 3 while the variation in the annual consumption rate of water was supplied by WHO (2003) and shown in Table 4. From the result, it was discovered that the annual effective dose equivalent ranges from $2.62 \pm 1.01$ to $4.95 \pm 1.43$ with a mean of $3.47 \pm 1.31 \mathrm{mSv} \mathrm{y}^{-1}$ for adults $(>17 \mathrm{y}), 2.75 \pm 1.03$ to $5.72 \pm 2.13 \mathrm{mSv} \mathrm{y}^{-1}$ with a mean value of $4.12 \pm 1.79 \mathrm{mSv}$ $\mathrm{y}^{-1}$ for children (7-12y), and $13.41 \pm 4.87$ to $18.85 \pm 6.43$ $\mathrm{mSv}^{-1}$ with a mean value of $15.47 \pm 6.08 \mathrm{mSv} \mathrm{y}^{-1}$ for infants (0-1y). These values are extremely higher than the $1 \mathrm{mSv} \mathrm{y}^{-}$ 
${ }^{1}$ recommended by the NCRP 1993. It was observed from the result that the annual effective dose equivalent is high for infants, this may be due to the radio-sensitivity of their various organs.

\section{Committed Effective Dose}

The committed effective dose was only evaluated for the adult age groups over an average life span of 50 years. The range of the values obtained was $131.00 \pm 50.50$ to $247.50 \pm$ $71.50 \mathrm{mSv} \mathrm{y}^{-1}$ with a mean of $173.25 \pm 65.50 \mathrm{mSv} \mathrm{y}^{-1}$

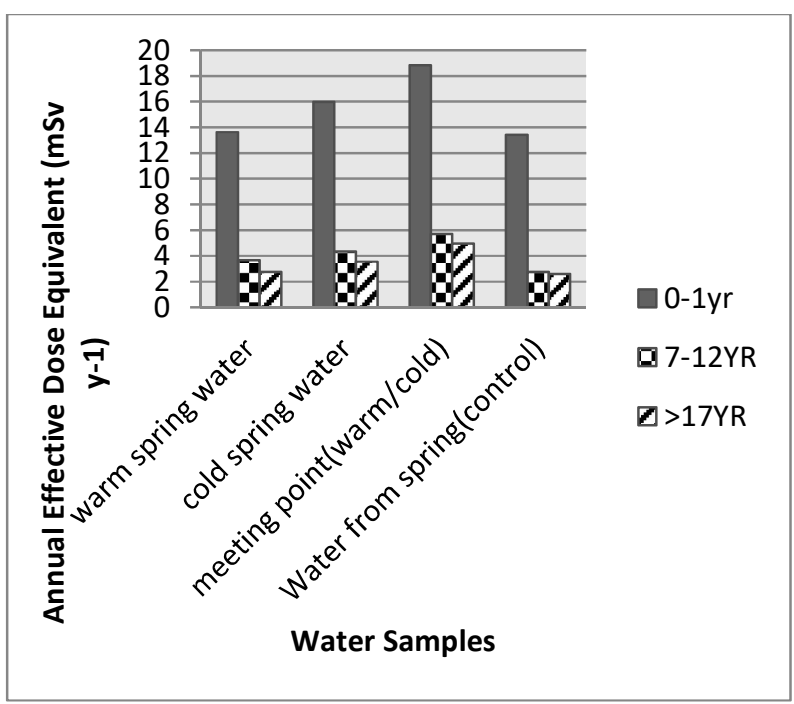

Figure 3 Annual Effective Dose for Three Different age Groups

\section{Activity Concentration in Sediment}

The same three primordial radionuclides found in the water samples were also detected in the sediment samples, i.e., the sediment samples also contained the activity of ${ }^{40} \mathrm{~K},{ }^{238} \mathrm{U}$, ${ }^{232}$ Th. From Table 1, K-40 had the highest activity among the three (3) radionuclides present while Th-232 had the least activity. The activity concentration of the radionuclides in the sediment samples compared reasonably well with the worldwide average concentrations of $400 \mathrm{~Bq} \mathrm{~kg}^{-1}, 40 \mathrm{~Bq} \mathrm{~kg}$ ${ }^{1}, 40 \mathrm{~Bq} \mathrm{~kg}^{-1}$, for ${ }^{40} \mathrm{~K},{ }^{238} \mathrm{U}$ and ${ }^{232} \mathrm{Th}$ respectively as reported by UNSCEAR, 1988. The activity concentrations of ${ }^{238} \mathrm{U}$ and ${ }^{232} \mathrm{Th}$ are relatively low compared with that of ${ }^{40} \mathrm{~K}$ and this can be explained by the fact that, ${ }^{40} \mathrm{~K}$ is an essential element it is abundant in the earth crust. The high percentage activity concentrations of ${ }^{40} \mathrm{~K}$ can be attributed to the presence of quartz that characterized the soils. This is consistent with Ahmed et al. (2006) who noted that the activity concentrations of ${ }^{40} \mathrm{~K}$ in sedimentary rocks depends upon the relative amounts of feldspar, mica and clay minerals that make up the mineral-aggregate sediments. It can equally be enhanced in the soil with the application of chemical-base fertilizer.

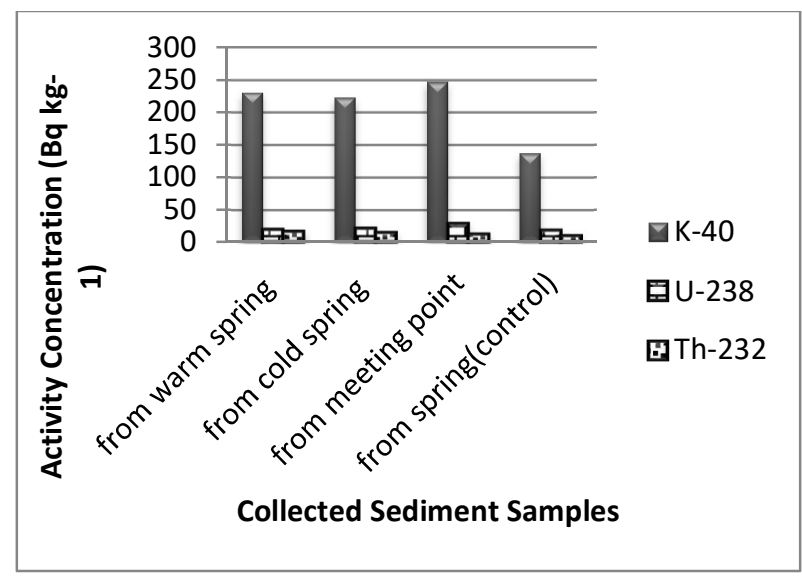

Figure 4: Activity Concentration of Primordial Radionuclides in the Sediment Samples

\section{Absorbed Gamma Dose Rates in Sediment Samples}

The evaluation of the absorbed gamma dose rates in air for the sediment sample was calculated also using this equation (UNSCEAR (2000).

$$
D=0.042 A_{k}+0.462 A_{u}+0.604 A_{T h}
$$

Where $A_{k}, A_{U}$, and $A_{T h}$ are the specific activity concentration for ${ }^{40} \mathrm{~K},{ }^{238} \mathrm{U}$ and ${ }^{232} \mathrm{Th}$ respectively in $\mathrm{Bq} \mathrm{kg}^{-1}$ and 0.042 , 0.462 and $0.604\left(\mathrm{nGy} \mathrm{h}^{-1}\right.$ per $\mathrm{Bq} \mathrm{kg}^{-1}$ ) are the concentrationto-dose conversion factors. Using equation 5 , the absorbed gamma dose rate in air for the sediment was determined and the results are presented in Table 5 .

This evaluation is summarized in Table 5 while the variation of the absorbed dose rates due to the individual natural radionuclide in sediment samples is shown in Fig 5.

Table 5 Absorbed Dose Rate in Air and Annual Effective Dose Equivalent for Sediment Samples from the Study Area

\begin{tabular}{|c|c|c|}
\hline Sediment & Total Absorbed & Annual Effective \\
\hline Samples & $\begin{array}{l}\text { Dose Rate in Air } \\
\left(n G y h^{-1}\right)\end{array}$ & $\begin{array}{c}\text { Dose Equivalent } \\
\left(\mathrm{mSv}^{-1}\right)\end{array}$ \\
\hline warm spring & $28.28 \pm 5.81$ & $0.052 \pm 0.011$ \\
\hline cold spring & $27.63 \pm 4.64$ & $0.05 \pm 0.009$ \\
\hline meeting point & $29.74 \pm 5.97$ & $0.055 \pm 0.011$ \\
\hline spring(control) & $19.78 \pm 6.13$ & $0.036 \pm 0.011$ \\
\hline Mean & $26.36 \pm 5.64$ & $0.049 \pm 0.010$ \\
\hline
\end{tabular}


The total absorbed dose rate from measured activity concentrations in the sediment samples was less than the world average value of 60 (UNSCEAR, 2000)

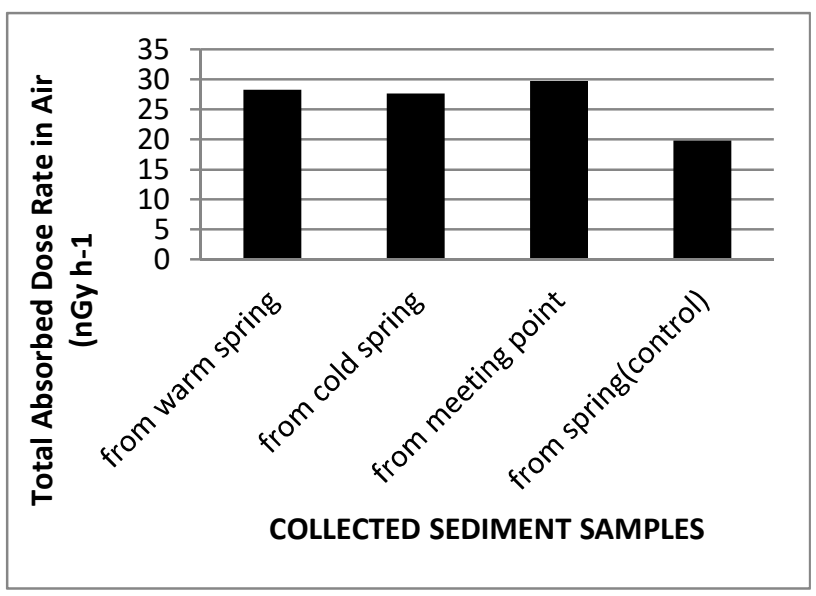

Figure 5 Absorbed Gamma Dose Rate for Radionuclides in Sediment Samples

The annual effective dose equivalent recorded for the sediment samples was calculated using equation 4 and the result is presented in table 5 . The value ranges from $0.036 \pm$ $0.011 \mathrm{mSv} \mathrm{y}^{-1}$ to $0.055 \pm 0.011 \mathrm{mSv} \mathrm{y}^{-1}$ with a mean value estimated at $0.049 \pm 0.010 \mathrm{mSv} \mathrm{y}^{-1}$. This value is lower and about $70 \%$ of the world average of $70 \mu \mathrm{Sv} \mathrm{y}^{-1}$ UNSCEAR (1988).

However, this annual effective dose equivalent is just about $4.9 \%$ of the $1.0 \mathrm{mSv} \mathrm{y}^{-1}$ recommended by the International Commission on Radiological Protection (ICRP, 1992) as the maximum permissible limit for members of the public. This value clearly establishes the fact that there is no potential danger to the health of the Ikogosi people due to radiological hazards from the sediments.

\section{CONCLUSION}

The activity concentrations of natural radionuclides, namely ${ }^{40} \mathrm{~K},{ }^{238} \mathrm{U}$ and ${ }^{238} \mathrm{Th}$ found both in the sediment and water samples collected from Ikogosi spring resort were measured. The mean absorbed gamma dose rate for the sediment samples is $26.36 \pm 5.64 \mathrm{nGy} \mathrm{h}^{-1}$. These values are less than the world average of 60 . The mean annual effective dose equivalents as a result of the ingestion of the spring water from the study area are $3.47 \pm 1.31 \mathrm{mSv} \mathrm{y}^{-1}, 4.12 \pm 1.79 \mathrm{mSv}$ $\mathrm{y}^{-1}$ and $15.47 \pm 6.08 \mathrm{mSv}^{-1}$ for for adult, children and infants respectively. These values are extremely higher than the $1 \mathrm{mSv} \mathrm{y}^{-1}$ recommended by the NCRP 1993. It was observed from the result that the annual effective dose equivalent is extremely high for infants and this may be due to the radio-sensitivity of their various organs. The mean committed effective dose is $173.25 \pm 65.50 \mathrm{mSv} \mathrm{y}^{-1}$

The annual effective dose equivalent for the sediment samples is $0.049 \pm 0.010 \mathrm{mSv}^{-1}$. The value is less than the world average $70 \mu \mathrm{Sv} \mathrm{y}^{-1}$ given by UNSCEAR (1988). It was also found that the activity concentration for the meeting point water sample contributes the highest possible radiation risks. The results showed that the tourists and populace living around Ikogosi spring resort are safe in respect to radiation exposure from the natural environment.

However, in the case of ingestion of water from the spring, the result showed an enhanced activity concentration in Ikogosi spring. The effective dose in the water is high compare to the NCRP recommendation of $1 \mathrm{mSv} \mathrm{y}^{-1} \mathrm{NCRP}$ (1993). It is therefore recommended that the Ikogosi water is not safe for human consumption, most especially the infants.

\section{REFERENCES}

1) Ahmed, N. K., Abbady, A., El Arabi, A.M., Michael, R., El-Kamel, A. H., and Abbady, A. G. E. (2006). Comparative study of the natural radioactivity of some selected rocks from Egypt and Germany. Indian Journal of Pure and Applied Physics 44:209-215.

2) Ajayi O. S., and Adesida G (2009). Radioactivity in some sachet drinking water samples produced in Nigeria. Iran J. Rad. Res. 7(3):151-158.

3) Ajayi, O. S. and Owolabi, T.P. (2007): Determination of natural Radioactivity in drinking water in private dug well in Akure Southwestern Nigeria. Radiation Protection Dosimetry 128, 477484.

4) Akinloye, M. K. (2008); Radioactivity in LAUTECH Water Supplies, Nigeria Nigerian Journal of Physics Vol 20 (1) pg 29-37.

5) Alam, M. N., Chowdhury, M. I., Kamal, M., Ghose, S., Islam, M. N., and Anwaruddin, M. (1999): Radiological assessment of drinking water of the Chittagong Region of Bangladesh. Radiat. Prot. Dosimetry 82, 207-214.

6) Avwiri G. O., (2005). Determination of Radionuclides Levels in Soil and Water around Cement Companies in Port Harcourt. J. Applied Sci Environ. Manage, 9: 27-29.

7) European Commission Directive 96/29/Euratom of 13 May 1996, Laying Down Basic Safety Standards for the Health Protection of the General Public and 
Workers against the Dangers of Ionizing Radiation. Official Journal L-159 of 29.06.1996, 1.

8) International Atomic Energy Agency, IAEA, (1989). Measurement of Radionuclides in Food and the Environment. Technical Reports Series No. 295. International Atomic Energy Agency, Vienna, 9) International Atomic Energy Agency (1996) Basic safety Standards for Protection against ionizing Radiation and for the safety of radiation Sources, (Safety Series Number 115).

10) International Commission On Radiological Protection (ICRP) (1992), “The 1990-91 Recommendations of the International Commission on Radiological Protection" Publication 60, Vol. 21, No. 1-3.

11) National Council on Radiation Protection and Measurements, NCRP (1987). 'Exposure of the Population in the United States and Canada from Natural Background Radiation'. NCRP Report No. 94, Bethseda MD 20814.

12) NCRP (1993). National Council on Radiation Protection and Measurements. Limitation of Exposure to Ionizing Radiation, NCRP Report No. 116 (National Council on Radiation Protection and Measurements,Bethesda, Maryland).

13) Nicolaidis S. Physiology of thirst. In: Arnaud MJ, editor. Hydration throughout Life. Montrouge: John Libbey Eurotext; 1998. p. 247

14) Nour K. A. (2004). Natural radioactivity of ground and drinking water in some areas of Upper Egypt. Tur. J. Eng. Env. Sci. 28:345-354.

15) Olomo J. B., Akinloye M. K., and Balogun F. K. (1994). Distribution of Gamma-Emitting Natural Radionuclides in Soil and Water around Nuclear Research Establishments, Ile-Ife, Nigeria. Nucl. Instr. Methods. Phys. Res. Section A, 353: 553557.

16) Rowland R. E. (1993). Low-Level radiation retention by body. A modification of ICRP publication 20 retention equation. Health Phys. 65:337-343.

17) Science Communication Unit, University of the West of England, Bristol (2013). Science for Environment Policy In-depth Report: Soil Contamination: Impacts on Human Health. Report produced for the European Commission DG Environment, September 2013. Available at: http://ec.europa.eu/science-environment-policy

18) Trimble, C.A. (1968). Absolute counting of alpha decay and the radioactivity in water from Hot spring National Park. University of Arkansas;

Thesis.

19) United National Scientific Committee on Effects of Atomic Radiation, (UNSCEAR), 2000: Sources and Effects of Ionizing Radiation. Report to General Assembly, with Scientific Annexes, United Nations, New York.

20) United Nations Scientific Committee on the Effects of Atomic Radiation (UNSCEAR). 1993. Sources and effects of ionizing radiation.

21) United Nations Scientific Committee on Effects of Atomic Radiation, (1988): Exposures from Natural Radiation Sources, UNSCEAR.

22) Wall B F, R Haylock, J T M Jansen, M C Hillier, D Hart and P C Shrimpton (2011). Radiation Risks from Medical X-ray Examinations as a Function of the Age and Sex of the Patient. Health Protection Agency, Centre for Radiation, Chemical and Environmental Hazards Chilton, Didcot Oxfordshire OX11 0RQ (HPA-CRCE-028)

23) WHO (World Health Organization), (1988): Derived Interventional levels for Radionuclide in Food (Geneva: WHO).

24) WHO (2003) World Health Organization Guidelines for drinking- water quality - Draft, Vol. 3, Chapter 9 (Geneva: WHO).

25) MapHill (2011), The Map of Ikogosi, http://www.maphill.com/nigeria/ekitiwest/ikogosi, Accessed on 12/11/2014, 5:00PM 